\title{
Public development plan based on \\ coproduction and slow principles: an analytical scheme by action research
}

\author{
Coprodução do plano público de desenvolvimento com \\ base em princípios slow: um esquema analítico por meio da \\ pesquisa-ação
}

\section{Magnus Luiz Emmendoerfer [a] [D], Brendow de Oliveira Fraga [b] [D], Mary Sandra Guerra Ashton [c] [D]}

\author{
[a] Universidade Federal de Viçosa (UFV), Viçosa, MG, Brazil \\ [b] Faculdade do Futuro, Manhuaçu, MG, Brazil \\ [c] Universidade Feevale, Novo Hamburgo, RS, Brazil
}

How to cite: Emmendoerfer, M. L., Fraga, B. O., \& Ashton, M. S. (2021). Public development plan based on coproduction and slow principles: an analytical scheme by action research. urbe. Revista Brasileira de Gestão Urbana, v.13, e20210020. https://doi.org/10.1590/2175-3369.013.e20210020

\begin{abstract}
This study aims to investigate and reflect on the evidence of a development plan based on the coproduction the population and the government of a small municipality, based on the principles of the Slow City Movement (SCM). A descriptive exploratory research was conducted with a qualitative approach. The main guiding strategy of the research, consisted of the action research method carried out in the municipality of Rio Doce, in Minas Gerais, Brazil. The results show that the space for dialogue between the population and the government was relevant and allowed the coproduction of a municipal planning with micro and macro elements and within the slow city principles. Also, traditional practices linked to culture with the use of local environmental resources were included, involving popular knowledge, technologies of social origin and the knowledge of the daily life of the community in a project of future desired by the population.
\end{abstract}

Keywords: Coproduction. Public Planning. Slow City. Action Research Method. Local Sustainable Development.

\section{Resumo}

Este estudo tem como objetivo investigar e refletir sobre as evidências de um plano de desenvolvimento baseado na coprodução da população e do governo de um município de pequeno porte, com base nos princípios do Movimento Slow City (SCM). Realizou-se uma pesquisa exploratória descritiva com abordagem qualitativa. A principal estratégia norteadora da pesquisa, consistiu no método da pesquisa-ação realizada no município de Rio Doce, em Minas Gerais,

MSGA is full professor, Ph.D. in Social Communication, e-mail: marysga@feevale.br

MLE is associate professor, Ph.D. in Human Sciences: Sociology and Politics, e-mail: magnus@ufv.br

BOF is professor, PhD Candidate in Public Administration, e-mail: brendowfraga@gmail.com 
Brasil. Os resultados mostram que o espaço de diálogo entre a população e o governo foi relevante e permitiu a coprodução de um planejamento municipal com micro e macro elementos e dentro dos princípios da cidade slow. Também foram incluídas as práticas tradicionais ligadas à cultura com o uso dos recursos ambientais locais, envolvendo o saber popular, as tecnologias de origem social e o conhecimento do cotidiano da comunidade em um projeto de futuro almejado pela população.

Palavras-chave: Coprodução. Planejamento Público. Cidade Slow. Método da Pesquisa-Ação. Desenvolvimento Sustentável Local.

\section{Introduction}

Due to the complexity and multidimensionality of contemporary public problems, the State finds limitations in the supply of public goods and services that are able to meet the desires of the various social groups that inhabit a locality. This limitation leads to the need for the various sectors of the society to seek alternatives based on community involvement in issues of collective interest, in order to provide better conditions for life in society and greater effectiveness in accessing public goods and services (Emmendoerfer et al., 2020).

Since federalism is the form of organization of the Brazilian State and the municipality is considered, a federative entity endowed with political and administrative autonomy, a series of challenges are presented to public management at the local level. For instance, it is the municipality that has to plan and manage resources, actions and policies to meet the multiple needs of the inhabitants of a given local territory (Grin \& Abrucio, 2019).

Therefore, the practice of planning in the public sphere, in its hegemonic conception, although there are nuances, is essentially technical, monological and part of the premise that the variables that make up the context of the planned action can be predicted and fully controlled (Forester, 2018; Matus, 1993). The replication of this logic in the context of public planning in the municipalities may cause limitations when based exclusively on the view of representatives of public power.

In front of that, the notion of coproduction of public goods and services are understood as the sharing of responsibilities and power between the State and the segments of society (Alford, 2014; Salm, 2014). However, either for efficiency, reducing the size and responsibilities of the State, or by the insertion of a more dialogical perspective in the production process of the common good, these experiences show that the decentralization of functions, as well as joint efforts between society, market and government, allow for a more complex view of the reality of the territory. This incorporates into the vision of the governmental planner, the needs and desires of the population expressed in elements that possibly would not be planned or prioritized by a technical planner in the exercise of traditional planning (Bovaird \& Löffler, 2013).

Andrade et al. (2008) also relate the planning to the quality of life of a certain community, so that the actions designed by the government need to prioritize the problems that afflict the population in a more direct way. Analyzing this statement, some of the premises of Matus (1993) and Huertas (1996) are observed with regard to the complexity of preparing a plan for the public sphere. Such assumptions consist of the fact that planners do not have total control over the variables that make up the planned reality, as well as that planning is inserted in a negotiation zone marked by asymmetric positions of power and conflicts of different rationalities (Flyvbjerg, 1998).

Therefore, a way to resignify the relationship of people is proposing alternatives based on local sustainable development because it a priori interest all of them. In this sense, alternative movements emerge, with the scope of promoting a new logic for contemporary public management, such as the Slow City Movement (SCM) defined by its scholars as an ecological and humanistic orientation to promote wellbeing and quality of life in cities (Carvalho, 2014; Emmendoerfer et al., 2020; Fraga et al., 2021).

This article does not wish to explore details about the SCM, but to take it as a situational and theoretical background for the realization of this research. In relation to the SCM, Carvalho (2014) argues that for its planning and realization, popular support is a key element. Therefore, the social actors need to be engaged 
and committed, and a system for communication between society and public management should be implemented. With these elements, it is possible for a city to develop within a slow philosophy, whose priority issues deal with the well-being of the population. In this context, the Slow City Movement has its ideological bases in the so-called Slow Movement (SM), as it has been treated by some authors (Bauer, 2016) whose philosophical reflections are composed of elements that denounce the cult of speed and thoughtless, monological and unidirectional progress. In this perspective, the insertion of this logic in the context of municipal public management could contribute to an articulation between the different social actors of a locality (Grin \& Abrucio, 2019). Together, public management agents and social actors are able to construct goods and services that will be outlined according to the configuration of the characteristic and identity aspects of a local or region.

This reasoning composes the concept of coproduction of public goods and services, as a form of articulation between government, private agents and society, with the scope of collectively producing goods and services for the community as a way of inserting citizens in the construction of policies and local actions (Salm, 2014). The essence of that is the idea of 'cooperation' that would automatically come with coproduction. In view of this, considering that there are different stakeholders with different rationalities in the context of local public planning in countries of the Global South (Watson, 2016) is cooperation really possible through co-production?

The argument of this paper is that the articulation of these actions needs a planning instrument capable of predicting scenarios and guiding collective efforts towards a desired future for the benefit of a community (Paludo \& Procopiuck, 2011). Based on researches that produced theoretical and empirical knowledge about the SCM (Honoré, 2006; Emmendoerfer et al., 2020) it is possible to verify that despite a critical bias in the discourse of its promoters and practitioners, the movement has a prescriptive character in its structure, adopting criteria, as will be described throughout this work, which can be used as a guideline for municipal development projects and even as a vector for the territorial innovation including marketing of cities (Emmendoerfer, 2019) with slow orientation (Karabag et al., 2012).

Therefore, the perspective adopted for the SCM considered a thematic orientation for development, which assumes the main premise of community participation and responsibility for the actions taken to transform the local reality (Fraga et al., 2021). In the context of this study, the principles of the SCM are used for the elaboration of a public planning of actions for local development.

In the context presented here, the following guiding question emerges: How might the population and the government of a small municipality coproduce a public development plan based on the principles of the Slow City Movement (SCM)? The objective is to reflect on evidences of the coproduction of a public development plan between the population and the government of a small municipality, based on the principles of the SCM.

\section{Coproduction of public goods and services in the local public planning context}

The classic definition of coproduction consists of "the process through which inputs used to produce a good or service are contributed by individuals who are not in the same organization" (Oström, 1996, p. 1073). This definition evidences the economic character of the concept and its relevance in crisis moments.

The concept of coproduction of public goods and services involves a series of aspects related to the multidimensionality of public administration as a field marked by different agents with multiple interests, many of them antagonistic and excluding. All of this, in a society whose scope of those who lead it consists, or should consist of the search and maintenance of living conditions of a certain community (Denhardt, 2012). Therefore, the focus of the present study resides in the coproduction of the public aspects within a society, that is, in the collective construction of goods and services of interest to all, through a process of interaction of the agents who are inserted in a local territory as the municipal.

Bovaird \& Löffler (2013) construct an argument that evidences the conceptual complexity of coproduction, casting on the same theoretical lights of areas of knowledge such as the economy, regarding 
a process of production of a good or service, considering elements associated with efficiency in the use of resources when producing public goods. In addition, the authors mention service management in association with elements related to the effectiveness of coproduced services and also deal with the psychology of consumption, since coproduction is related to attitudes, behaviors and perceptions of users of a public good or service. Therefore, coproduction is a strategy for public management and can be understood as means to meet the multiple needs and demands of the various agents involved in a community, who can be planners and users of coproduced public goods.

In this respect, Alford (2014) also raises the question of the Service-Dominant Logic o (S-D Logic) in the public service, which is based on premises such as the fact that coproduction in the public service is an inevitable act and that coproduction and citizen participation are linked. The S-D Logic arises from gaps in the current theories of public administration, especially in importing business administration models into the public sector, which can be seen in the new public management model (Alford, 2014).

Highlighting the issue of services, Osborne et al. (2016) delimit the concept of coproduction, placing it as a dimension of public administration, based on the theory of service management, in which the user's own involvement in any project management or delivery of a public good or service characterizes it as a coproduction. These authors also state, in discussions on the question of value perceived by the user of a service, that the practice of coproduction leads to the generation of public value, since it contributes to the meeting of social objectives and to the cohesion or the well-being of the community.

The literature on coproduction, although showing some increase, still presents a gap in terms of a more robust conceptualization of the term (Osborne et al., 2016). In an attempt to mitigate this unresolved issue, the aforementioned authors propose a concept based on the S-D Logic, which links coproduction directly with the codesign of value for the user. Thus, based on the nature and locus of coproduction, a typology to classify the coproduction is proposed in the Table 1.

Table 1 - Conceptualising coproduction

\begin{tabular}{|c|c|c|c|c|}
\hline & & \multicolumn{2}{|c|}{ Locus of coproduction } & \\
\hline & & Individual service & Service System & \\
\hline \multirow[b]{2}{*}{$\begin{array}{l}\text { Nature of } \\
\text { coproduction }\end{array}$} & Involuntary & I. coproduction & III. coconstruction & \multirow[b]{2}{*}{$\begin{array}{l}\text { Towards } \\
\text { cocreation } \\
\text { (or codestruction) } \\
\text { of value }\end{array}$} \\
\hline & Voluntary & II. codesign & IV. coinnovation & \\
\hline
\end{tabular}

Source: Osborne et al. (2016, p. 645).

In this perspective, coproduction (I) can be understood as a manifestation in which it is possible for an individual or group of individuals to satisfy their individual needs, whether being socially reflective or not, through the sharing of efforts. In codesign (II) the social force of events implies that individuals organize themselves voluntarily in order to produce the public good. In coconstruction (III), the scope is very similar to coproduction, however the collective efforts are reflected in a set of services. Finally, in coinnovation (IV) a group of individuals is organized to mitigate collective problems through a set of specific services that range from design to the implementation and control of public services, through which value is added to service users (Osborne et al., 2016).

The study by Brudney and England (1983) stands out, which define two dimensions of coproduction analysis. The first is more social and resides in the fact that citizens are directly involved with a certain public good or service, because they want better conditions for the space in which they live, as well as they want to benefit from the improvements resulting from their participation. The second dimension explored 
by the authors consists of the economic dimension, in which there are two clearly defined agents: the regular producer, who leads the process to be coproduced and assumes most of the responsibilities, and the coproducers, who, from a service perspective, generally consist of consumers.

These coproducers, at a certain point in the process decide to contribute to the design or delivery of public services such as health, education, security, tourism, culture and other sectors of public administration (Brudney \& England, 1983). The economic nature of coproduction can be seen in the Figure 1 , in which the authors understand that there are producers and consumers of a given public service. In this sense, there is a set of common activities among the actors involved that in fact will characterize coproduction.

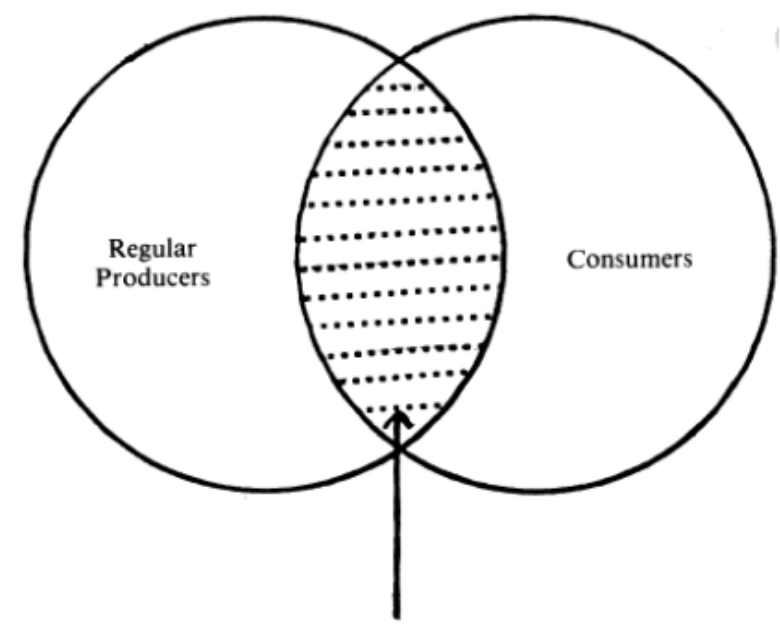

Figure 1 - Coproduction model of service delivery. Source: Brudney \& England (1983, p. 61).

In the aforementioned relationship between regular producers and citizens, the provision of the service, the activities of civil servants will be shared with citizens in order to make the results of the service different from a perspective in which the State simply delivers a product to its 'citizen customers' (Parks et al., 1981). In this way, one of the possible benefits of coproduction lies in the fact that when users are actively involved in proposing improvements or even in the creation of a public service, its design becomes more consistent with the real needs of users, who see contribution to the formulation of a public good or service is a way to achieve their longings for social changes.

The notion of public good, involves aspects related to the notion of public life, public responsibility and the sharing of a good that belongs to everyone. This good is configured by the fact that it benefits and unites a collectivity in a wide way (Matteucci, 2008). In this sense, Boyle \& Harris (2009) defend coproduction as a new way of thinking about public services. This change resides in the fact that the delivery of public services has its design changed due to the insertion of new actors in the dynamics of the process. Those who habitually act as users start to coproduce the planning, execution or delivery of a service.

Since the eighties, the dysfunction of citizen participation in political processes has been studied and problematized based on the central argument that the dominant model of relationship between the government and the citizen limits important aspects of the exercise of citizenship. Sharp (1980) proposes coproduction as an alternative to the planning and execution of a more qualified public service, both by allowing people to contribute to public goods and services that they themselves enjoy, and by bringing public officials the role of activators of citizenship and community involvement with the common good.

Boyle \& Harris (2009), looking a public service, argue that the relationship between the regular producers and the coproducers of a public service (companies, third sector and citizens) should be based on reciprocity, in the breadth of communication and constant negotiation, based on the real desires of those who will use the public services.

Since the concept has emerged and discussions about coproduction began in the public sphere, an element that draws the attention of scholars is the expressive dimension of volunteering in coproduced 
activities, by the users of a public good or service. Such involvement on the part of citizens is justified by some authors (Parks et al., 1981; Alford, 2014) as the result of the need for effective and accurate services to meet the complexity of the problems that involve a certain activity (Verschuere et al., 2012). The reader is therefore invited to reflect on the multilateral nature of public issues, many of which fall into sectors that are more directly related to commercial activities and the generation of foreign exchange, such as tourism.

By proposing a study on the state of the art in coproduction, Verschuere et al. (2012) argue that one of the profound theoretical gaps in research on the subject is the absence of studies on the effects of coproduction, whether in design, in the delivery or control of goods and services, comparing them with the results of a non-coproduced process. It is noteworthy that there were no studies in the literature accessed that evidenced the impact of the type of actor who leads the coproduction of a public good or service on the results obtained. That is, no research was found that showed the prioritized objectives in relation to what will be sought through coproduction, or even what are the main results obtained, in relation to the nature of the agent that is leading the coproduction process.

Furthermore, through coproduction, the balance of power is reconfigured, since its main assumption is the sharing of attributions between producers and users of a public service (Sharp, 1980; Boyle \& Harris, 2009; Salm, 2014). If this does happen, based on Flyvbjerg (1998), the citizens, in the context of a democratic state, feel their possibilities of acting in the public sphere expanded and manage to better understand the functioning of the public machine. When agents who are normally outside the planning, designing and delivering process of a public good or service, they are invited to understand and intervene in such processes. This participation generates a phenomenon of greater involvement over the limitations of the state in the provision of actions that meet the needs of a community, as well as enables individuals to demand greater effectiveness in public management.

Planning, as a practice of foreseeing scenarios and projecting possibilities of action in a community, has been present since ancient civilizations. However, the dynamics of planning as it is currently conceived, systematized through techniques and the formulation of plans has started at the end of the 19th century (Paludo \& Procopiuck, 2011). The concept of planning generally disseminated in theory and practice in administration, has its intellectual bases in a utilitarian, positive and rational thought. In addition, the functionalist approach has guided the pioneer constructions regarding the planning process, emphasizing the proposal of action flows necessary for the achievement of previously defined ends, with a view directed to the maintenance of systematic order than to a change in the social scope (Bergue, 2011).

The present study does not intend to advance the discussions regarding the theoretical formation of thought in planning. However, the scope of the passage previously presented was to point out elements that endorse the idea that the hegemonic notion related o planning is inserted in an instrumental and utilitarian reasoning. Furthermore, the bases of this concept are still widely present in the current notion of the practice of planning both in the private and public spheres, despite the gradual growth of the effectuation logic to the detriment of the dominant predictive logic (Emmendoerfer, 2019).

In this sense, Figure 2 illustrates a matrix was adopted based on Huertas (1996) that shows a possible typology of the planning process according to the actors involved and the scope in which it is applied. 


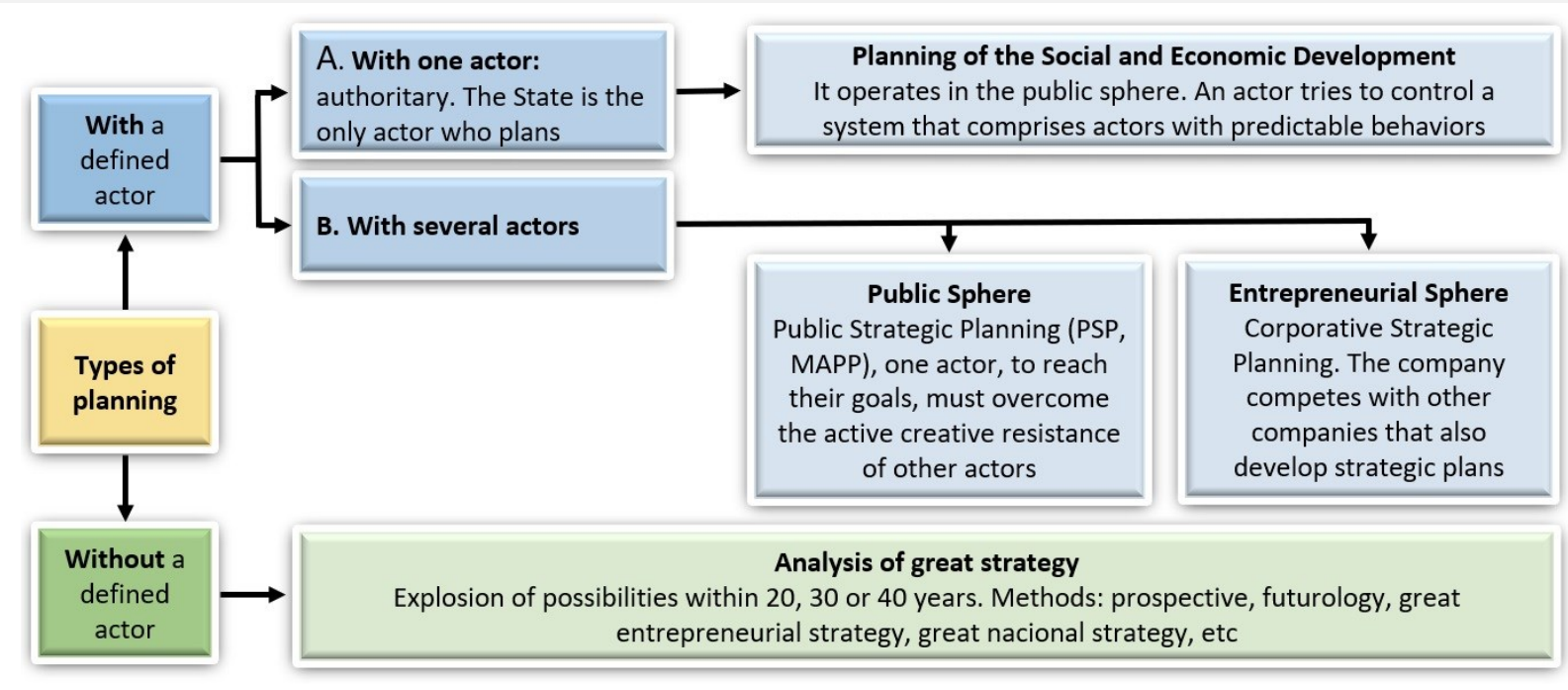

Figure 2 - Types of planning in the public sector. Source: Huertas (1996, p. 22).

The matrix presented in Figure 2 evidences that the presentation of the existing perspectives in planning are oriented exclusively to the public sphere and to the case in which there are actors defined for the making of the plan, whether technical or organized. In this way, this article intends to advance in the perspective of understanding co-production as a new public governance tool (Sorrentino et al., 2018), however with the focus in the municipal public planning for local sustainable development, based on principles of Slow City Movement (SCM) by Action Research method.

Such a study will provide the best exploration of this object both by the academic community in the construction of analytical schemes, via scientific investigations with an empirical approach, and by political leaders, public policy analysts and urban managers who will be able to guide their policies and actions based on the findings and search for better theories (Sabatier, 2007) to deal with public problems at the local / municipal level.

\section{Methods}

This research has qualitative approach and a descriptive character, aiming at comprehending the subjective and complex aspects that provide references about the reality in which these aspects are situated (Flick, 2018). The main guiding strategy of the research consisted of an Action Research (AR) carried out in the city of Rio Doce, that developed public planning in co-production with the local population to legitimize itself as the first Brazilian Slow Small City (Emmendoerfer et al., 2020).

The design of the present research went through five significant moments that were fundamental for the realization of the theoretical and methodological perspectives, as well as for the analyses that were performed (Figure 3). 


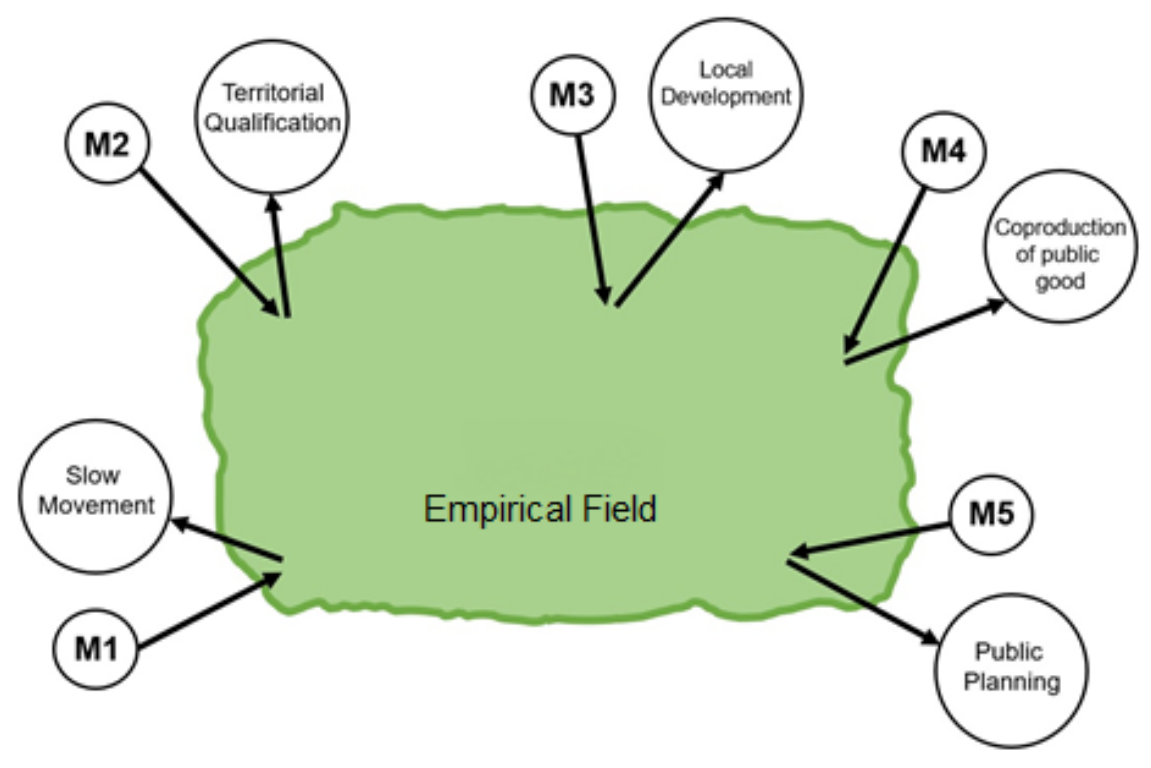

Figure 3 - Theoretical design of this research. Source: Own elaboration with data research.

According to Figure 3, each of the ' $M$ ' marks represents a significant moment in the present study, which emerged from the interaction of the researcher with the analyzed phenomenon. This occurred probably because there are different rationalities of power reveling situations of coproduction in different democratic spaces (Flyvbjerg, 1998). Here, were five main different moments with conflicts of ideas that required dialogues and consensus to advance in the public planning process in this study.

In M1, the researcher believed it would be necessary to investigate in depth the existing literature on the Slow Movement in order to understand its scope and to seek theoretical contributions to the existing literature. This search showed that the existing literature was incipient and monological, very limited to empirical aspects of the SCM (Emmendoerfer et al., 2020) and that a more comprehensive literature was sought.

M2 started with the initial contacts with the possible research subjects and we realized that the current management of the city, as well as representatives of the community organized in associations, wished to develop an initiative that would qualify the city and publicize the good indicators and the quality of life present in the territory. From this insight, we sought to access references in the existing literature on "Territorial Qualification" or Marketing of Cities/Places/Territories. However, the economic, instrumental and functional character of this perspective would not be sufficient to explain the richness of the community process and the interaction between government and society that was intended in the present study.

In the next moment, M3, a broader and more comprehensive approach was sought as a theoretical lens for the present work. This was due to a greater understanding of the interests both in the city of Rio Doce, and in what underlies the SCM, which reside in the idea of development at the local level. However, the specificities of the field and the participatory character of initiating a social process whose changes would be achieved long after the completion of the present research, showed us that the investigated reality needed more specific lenses that would allow the construction of more robust results and more consistent with what was given the time of execution of the present study.

Thus, development was seen as a secondary element, that is, as a background for the actions that permeated the present investigation, but which needed a more specific reference. From an understanding of the peculiarities of the field and also by the requirement expressed in the SCM guidelines on community protagonism in the proposal, we found that it could be analyzed through the theoretical lens of the coproduction of public goods and services. This understanding composed M4.

Finally, M5 was the last significant moment for the theoretical choices of the present work and the subsequent elaboration of categories of analysis. M5 occurred through the speeches of the mayor and the interaction with social actors associated with the public service when the viability of carrying out the 
research was being verified. The SCM served as a guideline for public planning, that is, as a kind of plan for the development of the municipality. This fact, coupled with advancing the interaction with the field, motivated the adoption of planning as one of the theoretical lenses of this research.

Regarding the definitions of the inferences intended with the study, we emphasize that because it is a research that contemplates the complexity of the process of social interaction of a heterogeneous group of individuals that is organized for the coproduction of a common good, it is not possible to generalize or generate hypotheses to be confirmed objectively. With the present research, we intended to understand the elements that compose the complexity of the analyzed process, as well as aspects underlying the proposed social interaction with the work, in the light of the accessed literature. In the context of the analyzed reality, our intention is to contribute to the existing theory, by identifying the elements to be considered in a similar coproduction process, thus facilitating and limiting the achievement of the proposed objectives, so that other researchers can advance their findings based on our proposals.

The present study has a large digital and technological dimension, that is, multimedia tools were used for data collection and for the investigation of the reality under analysis. Facebook profiles, WhatsApp groups and online forms were used as tools to guide the research process on development plan of the city studied. A more computerized approach is legitimate in view of the reality of the new times, in which digital connections make up a considerable part of the routine of individuals and the way in which they conceive reality about of the urbanity, the city and them daily life (Tranos, 2020).

Guidelines proposed by Thiollent (2018) on the acquisition of multiple knowledge on the subject were followed, in order to acquire knowledge and experiences to deal with the situation of planned change experienced in the realization process. From this, the analyses turn to the AR process and its main theoretical and empirical developments.

Our insertion in the field occurred in a planned way and required theoretical preparation in order to enable the analyses and reduce the bias arising from the truths, beliefs and preconceptions when establishing a relationship with an object to be known.

In the present research, the flexibility of the AR method is ratified, mainly due to the situational character of this type of study (Thiollent \& Silva, 2007). However, the use of the method showed the great psychosocial responsibility of its application, since the researcher is given the role of moderation and reference for everything that involves the initiative. The involved parties expect the researcher to have answers and full control over the variables that involve carrying out the research. This fact demands preparation and absolute dedication to the research context, so that, if answers cannot be given, the researcher may be able to conduct new questions.

\section{Analysis and discussion of results}

A literature survey showed that the reality of the SCM fundamentally includes community protagonism, that is, the direct involvement of citizens, organized in a working group for the maintenance and promotion of the proposal, at least at discursive level. Thus, it was possible to developing scientific work, broadly linked to action and planned change in a given social context, that at the same time that produced new knowledge, helped citizens in solving a public problem.

Once the feasibility of conducting the research was verified, public and open meetings were initiated to raise community awareness of the proposal. Three meetings with the same content were held in Rio Doce local government mandate (2017-2020) so that the population could become aware of the existence of the initiative and arouse interest in getting involved with the proposal. At each meeting, those present were consulted if they would like to volunteer for a committee whose functions would be related to collectively reflecting on issues related to the SCM and city development.

During this period, secondary data related to the characteristics of the municipality were collected in order to understand the local situation and the vectors through which the city could plead their development. 
Subsequently, a meeting was held with the mayor of the municipality, the communications adviser (founder of the demand), the secretary of government as well as the authors of this research. At the meeting, the research and protocols were defined and the free circulation of the researchers was authorized in government spaces so that the AR could take place. The government support was a major factor in carrying out the work and can be understood as a factor that favors the coproduction of public planning.

The understanding of the proposal by the main political agents of the municipality, such as the mayor and the government secretary, encouraged and favored the research and expanded the possibilities of the initiative. As much as the initiative requires the participation of the community, the practice of the research showed that the initiative normally comes from representatives of the public service and that the seal of the local authorities is an important element in the introduction of the process at the municipal level.

Once the government's interest was verified, a process of verification of the public interest was initiated through open meetings, previously disclosed, in which citizens were officially and personally invited by the city in order to foster broad community participation in the process.

Through voting and volunteer requests for the composition of a Slow City Committee, as a first institutional design for deliberations and consultations in relation to the development of the proposal, the interest of the population and its favorable reaction were verified. The reactions of the participants were euphoria, curiosity and it was felt in certain interlocutors, the intention to test or challenge the researcher to validate or verify the robustness of the project. Public officials, students, councilors, municipal councilors, educators and civilians were present at these meetings.

An interesting aspect is that even without the modeling of the researcher to such a configuration, the first meetings had a lecture aspect, as if the goal were just talking about something unrelated to the municipality and not on a future development for the municipality. This understanding was only reached after some meetings, when the interlocutors could assimilate the idea in a more assertive way. Even though a simpler and more accessible communication was planned, the public was not reached fully. Soon, the content of the meetings was further simplified.

In order to obtain a preliminary reading on the reality of the municipality in the view of those involved with the meetings to verify the popular interest, a survey was applied to those present, composed of only one question that read "In your opinion, what does Rio Doce need to become an even better city?". Considering the composition of the public at the meetings, composed of individuals with different levels of education, different socio-economic and cultural realities, responses were authorized by means of a drawing, if the interlocutor felt more comfortable doing so.

The manifestations of the sharing of responsibilities and power between citizens and public authorities were manifested in different episodes of the present study. In this perspective, in order to systematize the analyzes and highlight the efforts of the actors involved in the provision of the public good, the following analysis was elaborated, which shows in which aspects the coproduction occurred, as well as their respective challenges.

The categories presented below emerge from the interaction of the researcher with the field, as well as the comparison of the reality analyzed with the accessible literature (Table 2). 
Table 2 - Empirical evidences from analytical categories of the coproduction in the public sector

\begin{tabular}{|c|c|}
\hline \multicolumn{2}{|l|}{ Coproduction } \\
\hline Analytical categories & Empirical evidence \\
\hline & $\begin{array}{l}\text { All members of the committee contributed with individual } \\
\text { efforts in the planning and implementation of actions, within } \\
\text { their own possibilities, on a voluntary basis, aiming at the }\end{array}$ \\
\hline Voluntary efforts & construction of the common good. \\
\hline & Those involved organized themselves for the distribution of \\
\hline Brandsen and Honingh (2016) & $\begin{array}{l}\text { suggestion boxes in the city, for the distribution of } \\
\text { pamphlets, in order to prospect people for the initiative, as } \\
\text { well as giving their contribution in the process of building the } \\
\text { plan, with interventions, opinions, analyzes and information. } \\
\text { Although the planning process was mostly conducted and } \\
\text { written by the author of the present work, for technical }\end{array}$ \\
\hline Planning process & $\begin{array}{l}\text { reasons, the information and the richness of the analyzes } \\
\text { were due to the perceptions and propositions of the }\end{array}$ \\
\hline Flyvbjerg (1998) & members of society who presented the real vision of the \\
\hline Forester (2018) & users public services, pointing out the most relevant \\
\hline Matus (1993) & $\begin{array}{l}\text { problems and the most urgent issues. This type of sharing } \\
\text { makes public actions and policies much more effective, as } \\
\text { they base the plan's orientation on the citizen's perspective. } \\
\text { As described in the methodological procedures of the } \\
\text { present work, there is a strong influence of argumentation } \\
\text { theory in action research, a fact that allows a more } \\
\text { dialogical approach in the placement of problems and }\end{array}$ \\
\hline Communication & $\begin{array}{l}\text { research themes. In this sense, throughout the process, } \\
\text { asymmetries in the communication process had to be }\end{array}$ \\
\hline Forester (2018) & mitigated constantly, since many of the limitations of \\
\hline Thiollent (2011) & $\begin{array}{l}\text { popular adherence to the project, were initially pointed out } \\
\text { as an effect of the inefficiency of the communicative } \\
\text { process, whether in the message in itself, inaccessible to the } \\
\text { interlocutors, or in the choices of channels, as in the use of } \\
\text { the internet, since the citizens of the rural area, as well as } \\
\text { older citizens are indifferent to this media in the analyzed } \\
\text { municipality. }\end{array}$ \\
\hline $\begin{array}{l}\text { Sharing power and } \\
\text { responsibilities }\end{array}$ & $\begin{array}{l}\text { The government, when opening its doors to an initiative of } \\
\text { this magnitude, shared with the citizens, the responsibility to } \\
\text { project a desired future for the city, as well as the power of } \\
\text { decision on courses of action to be followed. It is }\end{array}$ \\
\hline Flyvbjerg (1998) & recognized, however, that there is a public agenda to be \\
\hline Salm (2014) & $\begin{array}{l}\text { respected, which can often differ with the objectives of the } \\
\text { research. However, by giving citizens the opportunity to use } \\
\text { an institutional space of speech of this nature, democracy is } \\
\text { strengthened. }\end{array}$ \\
\hline
\end{tabular}

Source: Own elaboration.

As Zeichner (1993) points out, AR allows for some types of changes, which were verified with the realization of this research. For instance, the development of professionals, since it enabled a greater understanding of those involved regarding public planning practices and made public managers more open to an innovative management perspective. Another change was institutional improvement, as it enabled the creation of a new municipal committee for planning and monitoring actions for local development based on the SCM, as well as social change, since it brought new projects and possibilities to the city. 
The execution of real projects based on the initiative and inspired by the SCM, shows that the main dimension of AR, which consists of the planned change in a reality through a research process that occurs from the active interaction between researcher and research subject (Thiollent, 2018) was in fact verified in the present study. In addition to the action and the collective construction of a work context, we tried to build an analytical model to assist future studies with a similar scope to this research, as shown in Figure 4 .

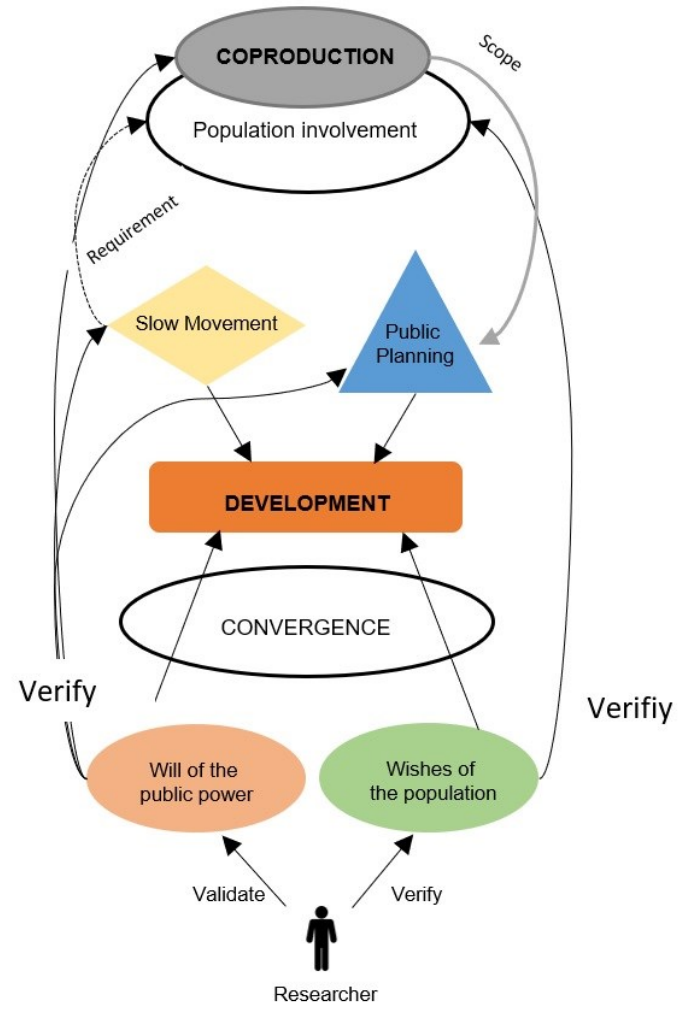

Figure 4 - Proposed analytical model of the investigated reality. Source: Own elaboration.

The explanation of the model is based initially on the researcher's role of verifying whether there is a willingness on the part of the public authorities in the context of the research, as well as the real interest of citizens to participate in a project whose scope is local development, as a common objective, systematized in an initiative shared between government and society. When the orientation for development considers the guidelines of the Slow Movement, the involvement of the community is important for the generation of relevant information for the making of a participative planning. The actions of the community result in a transformation of the social reality, through the guiding principles of the SCM. In the present work, the guiding principles of the SCM were identified as the valorization of the production and consumption at the local level, the maintenance of the values and historical and cultural manifestations of the place, as well as the development of participatory actions, which aim to make citizens more active and participants in the planning, implementation and control of public actions in order to qualify and develop the territory.

In this way, Thiollent \& Silva (2007, p. 95) define the following analysis criteria, which were adopted in the present study to verify the actions implemented, as well as seeking to validate the method, its application and the empirical technique employed, as described below (Table 3). 
Table 3 - Validation of Action Research (AR) in community and socio-environmental contexts

\begin{tabular}{|c|c|}
\hline Criterion & Verification in the research applied \\
\hline $\begin{array}{l}\text { It enables significant level of } \\
\text { involvement. }\end{array}$ & $\begin{array}{l}\text { The social mobilization meetings were public, in an open space } \\
\text { accessible to the entire population and previously published in } \\
\text { the local media. This allowed people who were interested to } \\
\text { volunteer for the initiative and compose the working group. }\end{array}$ \\
\hline $\begin{array}{l}\text { It empowers people in } \\
\text { performing tasks. }\end{array}$ & $\begin{array}{l}\text { All coproduced documents, analysis techniques such as } \\
\text { the Tree of Problems and analyses of the local context, had a } \\
\text { previous training session, an explanation of how to do and lessons } \\
\text { on the benefit of the initiative for public administration and the } \\
\text { community. In addition, several training sessions were held to } \\
\text { explain the Slow movement as a development model. }\end{array}$ \\
\hline $\begin{array}{l}\text { It supports people to learn to } \\
\text { act with autonomy. }\end{array}$ & $\begin{array}{l}\text { Long-term autonomy and self-management capacity was one of } \\
\text { the initiative's main objectives. In this regard, the importance of } \\
\text { institutionalizing the group to maintain the practices developed is } \\
\text { emphasized. }\end{array}$ \\
\hline $\begin{array}{l}\text { It strengthens plans and } \\
\text { activities that people are } \\
\text { able to carry out on their } \\
\text { own. }\end{array}$ & $\begin{array}{l}\text { Any citizen could individually analyze public problems and refer } \\
\text { them to the city hall. However, when this analysis is collective, } \\
\text { systematized and shared in a group movement, the voice of users } \\
\text { of public goods and services is amplified. }\end{array}$ \\
\hline $\begin{array}{l}\text { It deals more directly with } \\
\text { people than through } \\
\text { representatives or agents. }\end{array}$ & $\begin{array}{l}\text { The statements that through the committee, a more spontaneous } \\
\text { and more authentic participation was experienced by those } \\
\text { involved, evidence that the researcher was able to create the } \\
\text { conditions for direct involvement and interaction with the project } \\
\text { volunteers. }\end{array}$ \\
\hline
\end{tabular}

Source: Own elaboration with from research data.

Table 3 showed the elements arising from the applied AR method, which were endorsed by the categories indicated in Table 2. These categories emerged from a theoretical analysis of the co-production phenomenon, which touches dimensions associated with the collective planning process. In this sense, it is noteworthy that the results and categories, derived from SCM, relate to voluntary efforts and communication, which is now practiced through specific codes related to SCM, whose meanings are shared and disseminated among its members in the studied city.

Thus, it was observed that the potential contribution of SCM to the enrichment of a participatory public planning process, based on the study carried out, involved outstanding aspects such as: the free and voluntary adhesion of individuals who want to contribute to the collective well-being; the valuing orientation towards the memory of the territory, sustainability and conscious consumption/production at the local level; the concern with infrastructure, with the urban network and with the landscapes; and the interchange between generations of residents with the scope of creating a collective education for citizenship.

Nonetheless, conditions such as shared power and responsibility, the design of collective actions for development, as well as the strengthening of popular collective initiatives, whose efforts bring autonomy and empowerment to the group, are elements that were as much present in the phenomenon analyzed here as they can be obtained in general planning. Thus, considering the collective and dialogical character of the plan is an important element so that it can democratically take place. Therefore, it can be affirmed from the process of coproduction of the analyzed planning is that the thematic set and the narratives that build the "Slow Philosophy" add value to the elements common to the planning in general, but relevant in collective and participative terms, for incorporating both instrumental and symbolic direction in its configuration.

Thereby, from the exposure of the applied process of the AR method with empirical data of the studied city, in dialogue with the theorical revision, it is possible to verify that the coproduction of public planning for local development, based on SCM principles is feasible for small towns. On this, the results could to support planning and monitoring the sustainable development of the local, which, in times of crisis, and 
under the SCM principles can be a condition for resuming growth with sustainability and resilience. Thus, this does not mean that this proposal cannot be applied in connection or under the orientation of other guidelines for local sustainable development in larger municipalities as Sustainable Development Goals SDG's of UN 2030 Global Agenda.

\section{Conclusions}

The opening of a dialogical space to think on municipal planning, provided the basis for the presentation of micro elements, with total consonance with macro elements, as in the discussions which, through the clamor for the return of practices such as washing clothes in the stream of the city, demanded the rescue of cultural traditions, as well as the revitalization of this environmental resource. Much of the data obtained refers to specific elements and episodic situations, since the structure of the meetings was conducive to the free dialogue and speech for the citizens involved. Based on the speeches, meanings emerged, and from these meanings the data for the analyses for the elaboration of the plan were collected.

Thus, with regard to the micro and macro elements observed in this study, some of the main conceived microelements are the group configuration inherent to the plan and the deliberative processes that emerged as a result of the planning, since the specifics and the set of evaluative aspects concerning the SCM brought their own language. Such language was evidenced through references shared by the group when dealing with long-term actions and commitments as important for local development, from the SCM perspective.

In practical terms, these microelements were materialized by the content of the composition of the voluntary efforts, manifested in proposals of an autochthonous, collective, educational, cultural, historical, patrimonial and touristic character. The macroelements associated with the co-production of the plan can be evidenced through the institutionalization of the idea and the movement, within the scope of the municipal public administration, making the movement an agenda item and giving it the legal seal, as well as the incorporation of the SCM and its dynamics in the daily and communicative practices of popular participation groups associated with social issues in the municipality.

It is worth mentioning that the ideological and symbolic strength of the SCM manifested itself in different moments of the research, in which, in the dialogical processes of collective deliberation and construction, many times, when a suggestion guided by the mainstream logic of economic development was pointed out, the group members themselves warned the others, saying "people, what about the Slow? Where is it?" The recurrence of such a situation, showed us that to work under a perspective of development, and benefit the implementation and communication of the proposal, as the playfulness of approach draws attention and arouses the interest of the people, contributes to group cohesion and focus on previously established principles.

In addition, the creativity and innovation existing in the proposal, reside, above all, in the fact that popular knowledge, technologies of social origin and the knowledge of the daily life of countless actors that configure the local community were considered in an equitable way in the composition of a multidimensional and integrated plan for a reliable projection of a desired future for all who occupy a certain territory.

It should also be noted that the initiative consisted of coproduction on two major levels: on the one hand, the cocreation between society and researchers, mapping the needs and problems of the municipality. Citizens were free to speak up and point out the most significant urgencies and problems according to their worldviews. After this process was completed, a new form of coproduction emerged. In this new phase, the local government, as well as people responsible for the legal assistance of the city, guaranteed the legal feasibility of the actions indicated by the population through legal and financial criteria, explaining in a transparent way to those involved with the planning, the applicability or not of certain actions and commitments. In addition, the participating professionals acted as partners in the project, offering information and clarification about local development, based on the guidelines of the SCM. 
Finally, new studies on the subjects discussed in this article need to be resumed and expanded, including applications in cities larger than Rio Doce. In these cities, the use of the concepts and methods discussed here could occur in a decentralized way by neighborhoods or groups of neighborhoods, in partnership with non-governmental organizations and leaders of the communities involved, using information and communication technologies (ICTs), such as social networks. Thus, local governments promote the existence of decentralized committees, articulated with a meta-committee or management council, for public planning in the intra-municipal territories in which there is interest or adhesion of the communities aiming at the development of places under other more adherent and pertinent guidelines where SCM can be one of them.

\section{Acknowledgments}

To Brazilian National Counsel of Technological and Scientific Development (CNPq) and the Minas Gerais Research Foundation (FAPEMIG). Additional thanks to the anonymous reviewers and editorial staff of URBE - Brazilian Journal of Urban Management for their valuable contributions to improvement of this paper. This study was financed in part by the Coordenação de Aperfeiçoamento de Pessoal de Nível Superior - Brasil (CAPES) - Finance Code 001.

\section{Data availability statement}

The dataset that supports the results of this paper is available at SciELO Data and can be accessed via https://doi.org/10.48331/scielodata.AC3YCN.

\section{References}

Alford, J. (2014). The multiple facets of co-production: Building on the work of Elinor Ostrom. Public Management Review, 16(3), 299-316. https://doi.org/10.1080/14719037.2013.806578

Andrade, N. A., Aguilar, A. M., Morais, E. M., Pereira, R. C. M., \& Fonseca, V. R. (2008). Planejamento governamental para municípios: plano plurianual, lei de diretrizes orçamentárias e lei orçamentária anual (2a ed.). São Paulo: Atlas.

Bauer, R. C. (2016). Movimento Slow Travel no contexto cultural do turismo no Brasil: desafios e perspectivas. (Dissertação de mestrado). Escola de Artes, Ciências e Humanidades, Universidade de São Paulo, São Paulo, Brasil.

Bergue, S. T. (2011). Modelos de gestão em organizações públicas: teorias e tecnologias para análise e transformação organizacional. Caxias do Sul: EDUCS.

Bovaird, T., \& Löffler, E. A. (2013). Co-produção de serviços públicos pelo utilizador e pela comunidade: trazendo de volta o público para o Estado. In H. M. C. Silvestre, \& J. F. F. E. Araújo (Orgs.). Coletânea em Administração Pública (p. 45-69). Lisboa: Escolar.

Boyle, D., \& Harris, M. (2009). The challenge of co-production. London: New Economics Foundation.

Brudney, J. L., \& England, R. E. (1983). Toward a definition of the coproduction concept. Public Administration Review, 43(1), 59-65. https://doi.org/10.2307/975300

Carvalho, R. M. R. (2014). “Lentidão”, território e bem-estar: o movimento da cidade lenta e a sustentabilidade do lugar. Periódico Técnico e Científico Cidades Verdes, 1(2), 73-89. http://dx.doi.org/10.17271/23178604222014714

Denhardt, R. B. (2012). Teorias da Administração Pública. São Paulo: Cengage.

Emmendoerfer M. L. (2019). Inovação e empreendedorismo no setor público. Brasília: ENAP. https://doi.org/10.5281/zenodo.4236805 
Emmendoerfer, M. L., Fraga, B. de O., Costa, V. N. G., \& Ferreira, M. A. M. (2020). Análise da inserção de cidades no movimento Slow City como diretriz de qualificação e inovação territorial. Desenvolvimento Regional Em Debate, 10(ed.esp.), 171-194. https://doi.org/10.24302/drd.v10ied.esp..3105

Flick, U. (2018). Designing qualitative research. Thousand Oaks: Sage.

Flyvbjerg, B. (1998). Rationality and power: Democracy in practice. Chicago: University of Chicago.

Fraga, B. D. O., Emmendoerfer, M., Costa, V. G., Neto, A. D. P., \& Júnior, A. C. D. S. (2021). Em direção ao movimento Slow City. Planejamento público coletivo na sustentabilidade de um pequeno município brasileiro. Cidades. Comunidades e Territórios, (Sp21), 191-206.

Forester, J. (2018). Planning in the Face of Power. In J. Stein (Ed.), Classic Readings in Urban Planning (p. 165-179). New York: Routledge.

Grin, E. J., \& Abrucio, F. L. (2019). Governos locais: uma leitura introdutória. Brasília: ENAP.

Honoré, C. (2006). Devagar: como um movimento internacional está desafiando o culto da velocidade (4a ed.). Rio de Janeiro: Record.

Huertas, F. (1996). O método PES: Entrevista com Matus. São Paulo: FUNDAP.

Karabag, O., Yucel, F., \& Inal, M. E. (2012). Cittaslow Movement: An opportunity for branding small towns and economic development in Turkey. International Journal of Economics and Research, 313, 64-75.

Matus, C. (1993). Política, planejamento \& governo. Brasília: IPEA.

Matteucci, N. (2008). Bem comum. In N. Bobbio, N. Matteucci, \& G. Pasquino (Orgs.). Dicionário de Política (8a ed., v.1, p. 106-107). Brasília: UnB.

Osborne, S. P., Radnor, Z., \& Strokosch, K. (2016). Co-production and the co-creation of value in public services: a suitable case for treatment? Public management review, 18(5), 639-653. https://doi.org/10.1080/14719037.2015.1111927

Oström, E. (1996). Crossing the great divide: coproduction, synergy, and development. World Development, 24(6), 10731087. https://doi.org/10.1016/0305-750X(96)00023-X

Paludo, A. V., \& Procopiuck, M. (2011). Planejamento governamental: referencial teórico, conceitual e prático. São Paulo: Atlas.

Parks, R. B., Baker, P. C., Kiser, L., Oakerson, R., Ostrom, E., Ostrom, V., Percy, S. L., Vandivort, M. B., Whitaker, G. P., \& Wilson, R. (1981). Consumers as coproducers of public services: Some economic and institutional considerations. Policy studies journal, 9(7), 1001-1011. https://doi.org/10.1111/j.1541-0072.1981.tb01208.x

Sabatier, P. A. (2007). The need for better theories. In P. A. Sabatier (ed.). Theories of the policy process (p. 3-17). Colorado, CO: Westview Press.

Salm, J. F. (2014). Coprodução de bens e serviços públicos. In R. Boullosa (Org.). Dicionário para a formação em gestão social (p. 48-50). Salvador: CIAGS/UFBA.

Sharp, E. B. (1980). Toward a new understanding of urban services and citizen participation: The coproduction concept. Midwest Review of Public Administration, 14(2), 105-118, 1980. https://doi.org/10.1177\%2F027507408001400203

Sorrentino, M., Sicilia, M., \& Howlett, M. (2018). Understanding co-production as a new public governance tool. Policy and Society, 37(3), 277-293. https://doi.org/10.1080/14494035.2018.1521676

Thiollent, M. (2018). Metodologia da pesquisa-ação (18a ed.). São Paulo: Cortez.

Thiollent, M., \& Silva, G. O. (2007). Metodologia de pesquisa-ação na área de gestão de problemas ambientais. Revista eletrônica de comunicação, Informação e Inovação em Saúde, 1(1), 93-100. https://doi.org/10.29397/reciis.v1i1.888

Tranos, E. (2020). Social network sites and knowledge transfer: An urban perspective. Journal of Planning Literature, 35(4), 408-422. https://doi.org/10.1177\%2F0885412220921526

Verschuere, B., Brandsen, T., \& Pestoff, V. (2012). Co-production: The state of the art in research and the future agenda. Voluntas: International Journal of Voluntary and Nonprofit Organizations, 23(4), 1083-1101. https://doi.org/10.1007/s11266-012-9307-8

Watson, V. (2016). Shifting approaches to planning theory: Global North and South. Urban Planning, 1(4), 32-41. https://doi.org/10.17645/up.v1i4.727 
Public development plan based on coproduction and slow principles

Zeichner, K. M. (1993). Action Research: personal renewal and social reconstruction. Educational Action Research, 1(2), 199-219. https://doi.org/10.1080/0965079930010202

Editor: Rodrigo Firmino

Received: Jan. 29th, 2021

Approved: Jun. 09th, 2021 